\title{
ISL NEWS
}

\section{6th CONGRESS OF EUROPEAN SOCIETY OF LYMPHOLOGY}

Domus Pacis

Santa Maria degli Angeli, Assisi, Italy

June 11-13, 2020

Abstract deadline: February 29, 2020

\section{Registration:}

http://www.gccongressi.it/congress/

Congress President: Marina Cestari, MD

\section{CONGRESS SECRETARIAT}

GC congressi

Via Pietro Borsieri, 12

00195 Roma

Ph: +39063729466 + 39063700541

email: andreina.mancini@gccongressi.it

website: www.gccongressi.it

\section{INTERNATIONAL SOCIETY OF LYMPHOLOGY \\ GENERAL ASSEMBLY MINUTES \\ September 26, 2019 • 9:00 AM, Buenos Aires, Argentina}

1. Call to Order: The meeting was called to order by President S. Michelini. The minutes for the last General Assembly in Barcelona were published in Lymphology 50 (2017), 210-214. Minutes were approved as published.

\section{Elections:}

Nominations were solicited from the floor to add to the slate proposed by the Nominating Committee. There were none. The Nominating Committee composed of M Andrade, M Ohkuma, $\mathrm{H}$ Brorson, G Manokaran, and S Michelini proposed the following slate of officers: President-Elect: M Amore (Buenos Aires) was the sole nomination and as such, the President asked for voting by acclamation which was approved. Executive Committee: Corrado Campisi-2 yrs (Genoa), O Leduc-2nd term (Brussels), G Manokaran-2nd term (Chennai), P Bourgeois (Brussels), S Hayes (Brisbane), N-F Liu (Shanghai), and T Yamamoto (Tokyo). Nominating Committee: M Andrade (Brazil), C Papendieck (Argentina). Auditors (elected): M Bernas (Fort Worth) and M Ohkuma (Saitama), The voting proceeded and the Nominating Committee slate was elected.

\section{Reports:}

\section{a. Presidential Report (S Michelini):}

President Michelini spoke about the honor of being President of the ISL. He worked hard for the 
benefit of patients (improved data collection, insertion of components of lipedema into the International Classification of Disease, and he looked to help both private and public systems). The Scientific level of the Society is high and the Journal continues to improve. We do need to work on the official website and we need to recruit more young people. The role of the Central Office is very important. They process the dues and manage the Society from countries all over the World. He thanked his supporters.

He then spoke about the ISL website and the need for updating. Secretary-General Witte added that there has been a new website under design from Rome (with Dr. Michelini). In addition, Corrado Campisi also offered his webmaster to assist along with Dr. Dimakakos in the update. The Central Office will proceed to update and publish the up-to-date website. President-Elect Szuba closed with saying everyone recognizes the need and we will await more information from the Central Office.

b. Treasurer's Report (A Pissas): The UBS Swiss account has been stable since the last General Assembly in Barcelona with a September 2019 balance of 15,200 SF (the bank takes 7 SF each month for maintenance). There is 3,080 SF in the Swiss checking account. The Central Office has broken even the last 2.5-3 years based on substantially reducing costs for Journal production and also online conversion has not needed transfer of funds for the proposed annual allocation for the Central Office, Journal, and 2017 ISL Presidential Prizes totaling \$1,050 (see awardees below in New Business).

\section{INCOME AND EXPENDITURES}

\begin{tabular}{llll} 
& Income (USD) & Expenditures \\
\hline $2017-18$ & $\$ 17,446$ & $\$ 17,446$ & $\begin{array}{l}\text { Office/Journal production-handling } \$ 14,396 ; \$ 1,050(2017 \\
\text { ISL Presid. Prizes); } \$ 1,050 \text { (E/H Member allocation) }\end{array}$ \\
$2018-19$ & $\$ 15,490$ & $\begin{array}{l}\text { Office/Journal production-handling } \$ 13,840 ; \$ 1,650 \text { (E/H } \\
\text { Member allocation) }\end{array}$
\end{tabular}

UBS Balance (SFr)

$\begin{array}{ccccc} & \text { UBS Bond } & \text { UBS Cash } & \text { Assets } & \text { Liabilities } \\ 2017-18 & 15,200 & 387 & 15,587 & 15,587 \\ 2018-19 & 15,481 & 269 & 15,750 & 15,750\end{array}$

\section{c. Secretary-General's Report (M Witte):}

1) The Society has 203 members from 38 countries (173 active members, 12 honorary members, 7 emeritus members, 9 young lymphologists, and 2 associate members). In the course of this business period, 32 new members have been accepted and 54 memberships were discontinued due to non-payment of dues, retirement, resignation, or death. The nations represented by this membership are as follows:

$\begin{array}{lllrlr}\text { Argentina } & 4 & \text { Hungary } & 1 & \text { Scotland } & 2 \\ \text { Australia } & 8 & \text { India } & 5 & \text { Singapore } & 2 \\ \text { Austria } & 2 & \text { Iran } & 1 & \text { South Africa } & 1 \\ \text { Belgium } & 4 & \text { Italy } & 10 & \text { Spain } \\ \text { Brazil } & 2 & \text { Japan } & 14 & \text { Sweden } & 2 \\ \text { Canada } & 5 & \text { Korea } & 2 & \text { Switzerland } & 4 \\ \text { China } & 5 & \text { Mexico } & 1 & \text { Taiwan } & 1 \\ \text { Czech Republic } & 2 & \text { Netherlands } & 4 & \text { Thailand } & 2 \\ \text { Egypt } & 1 & \text { Peru } & 1 & \text { Turkey } & 1 \\ \text { Finland } & 1 & \text { Philippines } & 1 & \text { United Kingdom } & 5 \\ \text { France } & 5 & \text { Poland } & 3 & \text { USA } & 53 \\ \text { Germany } & 7 & \text { Russia } & 4 & & \\ \text { Greece } & 3 & \text { Saudi Arabia } & 1 & & \end{array}$


2) The 26th World Congress of Lymphology held in Barcelona, Spain from September 2529, 2017, was a great success where more than 50 renowned experts met with $\sim 400$ registrants including patient attendees. Basic science sessions were complemented by panels, oral presentations, and posters on latest advances in basic and clinical lymphology including management of lymphedema particularly imaging and surgical approaches. The meeting venue and arrangements were congenial and the dining and sightseeing options diverse. The social events kicked off with the opening reception. Special highlights of the Congress included the Color Night at Restaurant 1881 and the Gala Dinner under the stars in the wonderful gardens and pool at the Hotel Fairmont Rey Juan Carlos I.

3) Three meetings of the Executive Committee were held during the 27th Congress on 9/25, 9/27, and 9/29/17. In addition to the reports of the President, Secretary-General, Treasurer, and Editor, the Executive Committee discussion items included the annual budget and proposed expenditures, status of Lymphology, membership, the Consensus Document, Young Lymphologists, collaborative research projects, and future meetings.

4) A revised up-to-date ISL Membership List containing names, addresses, telephone, FAX numbers, and E-mail addresses in alphabetical order (with key research/clinical interests) along with a listing of ISL members by country is available in pdf format at the ISL Membership table or requested by e-mail from the ISL Central Office. The ISL Membership Directory is provided to ISL members only, and the listing should not be used for commercial purposes. The list should not be reproduced by members and/or sold or distributed to non-ISL members or other groups or associations. Please update personal information at the Central Office desk or send e-mail to grace@surgery.arizona.edu.

[Addendum: Members were urged to maintain active status by paying their annual dues by March 31st.]

\section{d. Editor/Journal Report (M Bernas):}

Eighty-eight (88) manuscripts were received since the last General Assembly (there were additional manuscripts in process at that time). We have published 49 since the last Congress and 43 were rejected (a few were withdrawn). There are 19 currently in the works. The journal website is working very well and all our past issues dating back to the first in 1968 are uploaded. (https://journals.uair.arizona.edu/index.php/lymph/index)

e. Young lymphologists - no formal meetings were held at this Congress but many young lymphologists presented and interacted during the meeting in Buenos Aires and also Iguazú.

f. Chapters and Regional Societies are functioning well.

\section{Future Congresses:}

a. 2021 - 28th Congress plans were presented by Dr. Dimakakos. He thanked Drs. Amore and Papendieck for this wonderful Congress. He presented goals of the Athens Congress. He would like to have the abstracts published in a supplement to Lymphology (possibly on the website). Courses will be included on conservative and surgical treatment with proposed certification from the ISL. He wants a very interactive meeting with enjoyment for all. Many flights to Athens, climate is good, and lots of history and cultural highlights. Wyndham Grand Hotel is booked for the meeting. He showed a video of Athens highlights and the Congress will be the last week in September with the slogan "Live your 
Lymph Dream in Athens" This plan has been approved by the Executive Committee and General Assembly in 2017.

b. $2023-29$ th Congress, Turin, Italy. CC Campisi will present more in Athens. This Congress was approved by the Executive Committee and General Assembly in 2017.

c. 2025 - 30th Congress

1) A proposal was presented by Pinar Borman for Turkey. Turkey is now safe with political affairs in order with easy visas and good food. Possibly Istanbul with much history and attractions as well as 2 airports. Site could also be Antalya which is on the Mediterranean. This is also an historic city with many sights to see. All hotels are inclusive with large conference centers (5 to 7 stars). There are over 500 people in the Turkish Society.

2) Dr. Manokaran presented an idea for the 30th Congress meeting to be in the city of Cochin, state of Kerala. He will be able to present more next time. It is safe with lots of hotels and economically stable. This could also be a possibility for 2027 .

d. Pierre Bourgeois brought a proposal from the floor that he was speaking on behalf of the ESL and since the 2021 and 2023 Congresses will both be in Europe they would like to propose that the meetings will be joint. This proposal was approved by the General Assembly.

\section{Consensus Document}

S Michelini explained how the Executive Committee has decided on a parallel Consensus for Lipedema since it is not appropriate to include so much information on lipedema in the document on peripheral lymphedema. A Szuba supported this concept since it is important to give direction to practitioners and many patients have both conditions. Maybe this effort could get started in the next few months. C Papendieck suggested that lipedema is not a good word, we need to change it. Szuba says that Allen and Hines defined this in their original description. Okhuma asked what is the interstitium and relation to fluid in lymphedema and what about lipedema?

\section{NEW BUSINESS:}

1. The following Young Lymphologists were presented 2019 Presidential Prizes at the Gala Dinner: Sara Dessalvi, University of Genoa, Italy; Tessa DeVrieze, University of Leuven and University of Antwerp, Belgium; Tobias Karlsson, Lund University, Malmo, Sweden; Aleksandra Rovnaya, First Pavlov Medical, St. Petersburg University, Russia; Adarsh Singh, All India Institute of Medical Sciences, New Delhi, India; and Takumi Yamamoto, MD, University of Tokyo, Japan

2. G Manakaran brought a proposal from the floor that he would like to support a medallion that the current president would retain during his/her term and would be passed on to the next President. He would provide the funding to make the medal and needs to have design ideas. This proposal was approved by the General Assembly.

3. A Szuba then took the microphone and thanked everyone for electing him as President. It is an honor for him and he will do his best especially in efforts to attract young people. Lymphology is growing and he is happy to see the growth in Surgery. He congratulated Drs. Amore and Papendieck on the Congress.

4. President Michelini closed the meeting and thanked everyone encouraging them to come to the Post-Congress in Iguazu for updating and revisions in the ISL Consensus Document on Peripheral Edema. 